\title{
The Bayeux 'Tapestry': invisible seams and visible boundaries
}

\author{
GALER. OWEN-CROCKER
}

The embroidered hanging known as the Bayeux 'Tapestry' was an obvious candidate for inclusion in an Anglo-Saxonists' conference titled 'Imagined Endings, Borders, Reigns, Millennia'. ${ }^{1}$ Almost certainly constructed in English workshops for a Norman master, ${ }^{2}$ the 'Tapestry' illustrates a chronological period that begins with the final years of Edward the Confessor's reign and ends with the closing of the Anglo-Saxon era. The physical termination of the 'Tapestry' is missing, but this does not preclude the imagining of it, usually as a scene showing the accession of William the Conqueror to the English throne, a new reign and a new, Norman, era.

The 'Tapestry' is composed of a naturalistic, narrative frieze edged at top and bottom by borders, which not only frame but also comment - symbolically, cryptically, ironically and humorously - on the main narrative of the dynastic power-game played out in the opening decades of the second millennium. Less formal, more subtle, borders are the buildings and trees which divide the narrative into scenes. Actions are carried out within these zones like chapters in a continuous narrative. Sometimes figures turn inward from the physical barriers to make enclosed scenes which appear self-contained. Yet the artist repeatedly violates the scene boundaries with graphic details that move the eye forward; and, scarcely appreciated by modern commentators, individual scenes find echoes and inversions elsewhere in the frieze, suggesting that events were seen to prefigure and recall one another.

${ }^{1}$ Ninth meeting of the International Society of Anglo-Saxonists at the University of Notre Dame, 1999. I am grateful for the award of a British Academy Travel Grant on this occasion.

2 Technically an embroidery rather than a tapestry, since the decoration is worked with the needle, not on the loom, the work's popular name comes from the French tapisserie. The hanging was almost certainly made in England, probably at Canterbury, as betrayed by occasional English spellings in the Latin inscription, particularly the Old English letter eth in the name GYRĐ; by general features of style; and by specific borrowings from manuscripts attributed to St Augustine's and Christ Church, Canterbury, including London, British Library, Cotton Claudius B. iv, Cotton Cleopatra C. viii, Harley 603 and Cambridge, Corpus Christi College 286; see D. J. Bernstein, The Mystery of the Bayeux Tapestry (London, 1986), pp. 28-81. It was probably created in the 1080s for Bishop Odo of Bayeux, half-brother of William the Conqueror, who was made earl of Kent after the Conquest, an appointment which would have given him access to Canterbury resources. 


\section{Gale R. Owen-Crocker}

Almost hidden are the boundaries we were not meant to notice: the neat, barely visible seams which, after the first botched join (pl. VIII), are concealed with increased sophistication as the two parts of the graphic design are correctly aligned and embroidery disguises at least part of each seam. We see, therefore, that the manufacture of the hanging was a learning process where artist met artisan, graphic artist both dictating the work of seam-stitchers and embroiderers and also adapting in response to the practical problems revealed once they had started work. It would surely have been easier to create a series of individual hangings. Why, we may ask, did the creators go to so much trouble to make a single continuum?

\section{SEAMS AND SCENES}

The Bayeux 'Tapestry' is more often appreciated for its art than as a piece of cloth, ${ }^{3}$ yet it is of major importance as a historical textile. It consists of a linen strip nearly seventy metres long, by far the largest surviving example of cloth from medieval Britain. The only existing medieval English textiles which could be described as 'large' are vestments, none of which rival the 'Tapestry' for size. Apart from the tenth-century embroideries from the tomb of St Cuthbert, and the late-eighth- or early-ninth-century composite vestment now in Maaseik, Belgium, most come from later in the Middle Ages. Almost all the known textiles from the Anglo-Saxon period are considerably earlier and consist of fragments measured in centimetres if not millimetres. ${ }^{4}$ The potential importance, therefore, of a piece of eleventh-century cloth the size of the Bayeux 'Tapestry', all uniformly hand-spun and woven, is obvious; but there has been remarkably little interest in it! The 'Tapestry' is made in eight sections, of different lengths,${ }^{5}$ which are joined by neat, barely visible seams. ${ }^{6}$ Here, one would think, is an important piece of evidence for the history of sewing, an activity of cultural importance since civilization began. ${ }^{7}$ Non-decorative sewing, and

${ }^{3}$ For technical details, see S. Bertrand, 'Les Éléments textiles de la tapisserie de Bayeux', Bulletin de liaison du Centre international d'étude des textiles anciens 6 (July 1957), 17-21; La Tapisserie de Bayeux et la manière de vivre au onzième siecle (La Pierre-qui-Vire, 1996), pp. 23-38.

4 The Manchester Medieval Textiles Project currently has documented over four thousand items of surviving medieval textile from the British Isles. Over three thousand of these are AngloSaxon, mostly grave-finds.

5 Approximate measurements of the sections are: $1(13.65 \mathrm{~m}) ; 2(13.75 \mathrm{~m}) ; 3(8.35 \mathrm{~m}) ; 4(7.75 \mathrm{~m}) ; 5$ (6.60m); 6 (7.15m); 7 (7.15m); 8 (incomplete 5.25m); see Bertrand, La Tapisserie de Bayeux, pp. 24-5.

${ }^{6} \mathrm{I}$ know of no reason to doubt that the seams are original. The 'Tapestry' is described as une tente très longue et estroicte ('a very long and narrow strip') when it emerges from obscurity to be described in the 1476 Inventory of the Treasures of the Cathedral of Bayeux; quoted in S. A. Brown, The Bayeux Tapestry: History and Bibliography (Woodbridge, 1988), p. 161.

${ }^{7}$ For a technical guide to methods of making a seam, see A. Morrell, The ATN Guide to Structural Sewing: Terms and Techniques, Archaeol. Textiles Newsletter Publ. (Leiden, 1989), pp. 15-18. 


\section{The Bayeux 'Tapestry'}

seams in particular, are poorly represented among earlier medieval textiles, and here we have seven stitched joins. However, observation of the 'Tapestry' seams is limited by the fact that it is permanently exhibited with the back concealed. The reverse side has been photographed, but the results are not published in their entirety. ${ }^{8}$

This lack of interest in the 'Tapestry' cloth is symptomatic of a culture which values the artist above the artisan, and so, incidentally, the designer, generally assumed to be male, over the probably female seamstress. (The embroiderers, who are usually assumed to have been female but who could have been of either sex, ${ }^{9}$ fall somewhere between the artist and artisan and there is some technical description of their work in most books on the 'Tapestry'.) This is no modern prejudice; the Anglo-Saxons appear to have had the same lack of interest in the cloth and its seams. Only twice does the end of a length of cloth correspond exactly with the scene boundaries. Otherwise the neat, almost invisible, seams render the limits of the linen strips irrelevant. However, a consideration of the joins, even excluding the technical details of how they were stitched, is illuminating. It can show how labour was distributed, and the sequence in which the work was carried out. It can show stylistic differences between workshops and, incidentally, by showing that some features are merely stylistic, can cast doubt on some of the conclusions that might be drawn about Anglo-Saxon and Norman material culture. ${ }^{10}$

The continuity of the Bayeux 'Tapestry' is an illusion of graphic design. In fact the frieze is an interrupted sequence in which one hand (or team of hands) continually gave way to another; but one in which the visible scenes take our attention from the humble joins we were not meant to notice. The links are

8 There is a black and white photograph of part of scene 47 in D. M. Wilson, The Bayeux Tapestry (London, 1985) [hereafter Wilson], p. 196, fig. 1; colour photograps of parts of scenes 50 and 57 appear in Bernstein, The Mystery, p. 80, pl. 44 and p. 151, pl. 88.

${ }^{9}$ It is usually assumed that the embroidery was carried out by women, even, despite the lack of evidence, that it was the work of William's queen, Mathilde. The few references to preConquest embroidery associate the craft with women, and the first evidence we have of a male English embroiderer is thirteenth-century (K. Staniland, Embroiderers (London, 1991), pp. 7-8 and 12). However, the testimony of the 'Tapestry' itself for the existence of workshops capable of producing large-scale commissions of secular embroidery in wool (as opposed to the silk and gold work of vestments) is sufficient to show how little is known about the organization of this obscure industry and to question traditional gendering. The weaving of such long strips must have been carried out on a horizontal loom, a 'male' piece of equipment.

10 The distinguishing features of the dress in the 'Tapestry' are discussed in detail in my essay 'The Bayeux "Tapestry": Culottes, Tunics and Garters, and the Making of the Hanging', Costume 28 (1994), 1-9. I will consider ships, furniture and architectural details in a future article, 'Embroidered Wood: Animal-Headed Posts in The Bayeux "Tapestry" ', Constructions of Wood, Stone and Ink: Papers in Honor of Rosemary Cramp, ed. H. Damico and C. Karkov (Kalamazoo, MI, forthcoming). 


\section{Gale R. Owen-Crocker}

betrayed by subtle differences in the graphic style of the needlework which suggests that the commission was so large that lengths of linen were given out simultaneously to be embroidered in different workshops. The differences between sections suggest that the master design was reinterpreted, perhaps by the draftsmen who put the design onto the linen, perhaps also by the embroiderers themselves. ${ }^{11}$ For example, the Normans, at their introduction in the first section of cloth, are distinguished by 'otherness' in costume and hairstyle. They wear culottes and sometimes have parallel gartering over hose or bare legs. Their hair is shaved from the back of the neck almost up to the crown, leaving their ears exposed, and often projects low over the brow in an intimidating way. The English, in contrast, wear tunics and ungartered hose. They have full heads of hair, neatly cropped round the ears and into the neck. They also have moustaches. The distinguishing features of the Normans diminish after the first seam. Men with the shaved hairstyle appear in tunics and the hairstyle itself gradually becomes less marked and consistent. The second workshop's images are stylistically similar to the first's, but some individuality is apparent: the earliest part of the second piece of cloth manifests a sudden popularity of crossgarters. This is short-lived. Perhaps it was the embroiderer's own idea and relieved the tedium of the job. Perhaps it was a misunderstanding of lines in the cartoon. Whatever the reason it began, it soon stopped. Maybe it was recognized that such depiction was not consistent with the first section; more likely perhaps, it was too time-consuming and time was money. The third, fourth and fifth sections of cloth have groups of people in different costumes reflecting, perhaps, different models for different occupations of protagonists and/or different hands at work on the embroidery, ${ }^{12}$ but these distinguishing marks blur by the end of the fifth section, after which armed figures predominate. ${ }^{13}$ The

11 There is no trace of a cartoon remaining on the linen and no evidence of what form an original design might have taken. It could have been drawn first on a long roll of parchment, but parchment rolls are not typical survivals from the period; a parchment roll on this scale would have been hugely expensive.

12 William and Odo at council (scenes 35 and 44) wear long garments; this may suggest a late antique model, probably transmitted through the Carolingian Utrecht Psalter to the Canterbury manuscript Harley 603, in which figures in long garments are shown seated within open buildings (the building itself in scene 44, though not the one in scene 35, is modelled on Harley/Utrecht; see C. Hart, 'The Bayeux Tapestry and Schools of Illumination at Canterbury', ANS 22 (1999), 117-67, at 135, fig. 7); Robert and some boat builders (the latter probably modelled on the Noah's ark sequence from Claudius B. iv, 13v) wear tunics. Woodchoppers wear culottes and men dragging boats have split-sided tunics or shirts. A woodcutter in ?split culottes and boat-loaders in stiff tunics with culotte-like lines suggest uncertainty on the part of the embroiderers.

13 Before settling down into consistency at scene 49 (Wilson, pl. 54) after which mail is usually depicted by large circles, mostly green, sometimes black, the embroiderers use squares, lozenges and smaller circles. In several cases a combination of styles or colours on a single figure 


\section{The Bayeux 'Tapestry'}

details of foliage and diagonal lines in the borders differ between the lengths of cloth, again suggesting different tracers or groups of embroiderers. ${ }^{14}$

Imposed on this organic structure of the seamed textile are text and a graphic design where new boundaries are drawn, unrelated to the physical limits of the lengths of cloth. The narrative is divided into scenes, which are quite clearly denoted and are numbered in a nineteenth-century hand on the backcloth to which the embroidery is now attached. A change of scene marks a change of location; the trees and buildings which divide the scenes, though stylized, fit naturally into the narrative, which, until the prolonged battle scene which has its own sequence of events, mostly involves the characters travelling from one place to another or engaging in some activity inside, or around, a building, usually talking, but also besieging/being besieged, swearing an oath, being crowned, and, in King Edward's case, dying. Figures at scene-ends who look back at their companions, or who travel from right to left, contribute to the sense that scenes are circumscribed and ensure that we can appreciate the significance of events taking place in those areas. Conversely, other devices sometimes override the scene borders and make us look beyond the enclosed fields: these include human figures angled the opposite way to the dividing tree or building which they touch, hounds running forward eagerly, pointing gestures and objects carried in the hand which project onward - a bird of prey being handed into a boat; a standard, sword or spear; even meat on a spit. The circumscribing device and the onward-looking device may work together; thus at scene 13 William's party rides inward, from right to left, to meet with Harold and Guy; but the last rider in William's group points to the right, onward (pl. VIII) ${ }^{15}$ Thus we are made aware that this is a continuing narrative; there is anticipation, cause and effect. The sheer quantity of travelling scenes, when protagonists journey on horseback or by ship, and even carry burdens from place to place, contributes to the illusion that this (by definition, static) embroidery depicts something active and continuous.

The end of the first piece of cloth corresponds to a scene end (scene 13), but the first join (pl. VIII) demonstrates a lack of co-ordination between textile

suggests more than one hand working on it, sometimes from opposite sides, for examples scenes 18, 22 and 52 (Wilson, pls. 21, 25 and 61, left).

14 The point is mentioned in C. Hicks, 'The Borders of the Bayeux Tapestry', England in the Eleventh Century: Proceedings of the 1990 Harlaxton Symposium, ed. C. Hicks, Harlaxton Med. Stud. 2 (Stamford, 1992), 251-65, at 251-2, n. 2, but is developed further below.

15 The full scene, framed by a building to the left and a tree to the right, may be seen in Wilson, pls. 13-15. This scene is discussed in detail in G. R. Owen-Crocker, 'Telling a Tale: Narrative Techniques in the Bayeux Tapestry and the Old English Epic Beowulf', Medieval Art: Recent Perspectives. A Memorial Tribute to C. R. Dodwell, ed. G. R. Owen-Crocker and T. Graham (Manchester, 1998), pp. 40-59, at 54-5. 


\section{Gale R. Owen-Crocker}

workers and graphic designer that suggests inexperience, or lack of sophistication in handling a piece of these proportions. There may have been consternation when the first and second sections were brought together for joining, with, seemingly, the main register and upper border already complete. In the main register, the ground line which usually curls neatly into the edge of the bottom border, or disappears under a foot, a hoof or a tree, is here left suspended and is not immediately resumed in the second strip. The space between the end of the scene proper and the dividing tree is unusually wide; the fact that the pair of birds in the upper border are apparently asleep may be a humorous comment on the absence of action beneath, but the lack of any attempt to join the mismatched upper borders suggests that the birds were completed before the join was made. The upper borders are out of alignment; one is deeper than the other. The diagonal bars which are a regular part of the upper border design, and which should have separated the pairs of birds, are omitted before the join, so that birds are juxtaposed at the end of the first and the beginning of the second section. Whereas in the first section the upper border has individual animals in their own spaces marked out by diagonal bars, ${ }^{16}$ alternating with plant devices in their own spaces, after the first seam the upper border animals are no longer in their own spaces and instead are placed in pairs, an arrangement that continues to the quicksands scene. After a representation of the Abbey of Mont Saint-Michel interrupts the border, the animals revert to occupying their own spaces. Only the bottom border shows no obvious sign of discontinuity at the joining point. It must have been completed after the seam because at this point some embroidery covers the suture, but I suggest that more than the junction was completed at this late stage. The upper and lower borders are not synchronized throughout the 'Tapestry' but the differences between them are most marked in the first section and the last. ${ }^{17}$ At the start of the first section the bottom border has animals in pairs sharing spaces, until representations of Aesop's fables take over at scene 4. Animals in their own spaces appear only briefly after the fables, before and between another series of scenes showing various human activities. The device of separating the animals by plants is not used in the bottom border until just before the first seam. These plants are very stylized, almost cruciform, versions of the trefoil-on-a-base or acanthus-motifon-a-base which had appeared latterly in the upper border (fig. $7 a$ and $b$ ). The very stylized version is more typical of the second piece of cloth (fig. $7 c$ ), where plants appear regularly in the bottom border, dividing pairs of animals. I would

16 Only at scene 4 (Wilson, pl. 4) do upper border animals share a space.

17 The closest similarities in arrangement of motifs and plant types are to be found between the latter part of the second section and the end of the sixth, where the battle takes over the lower border. 


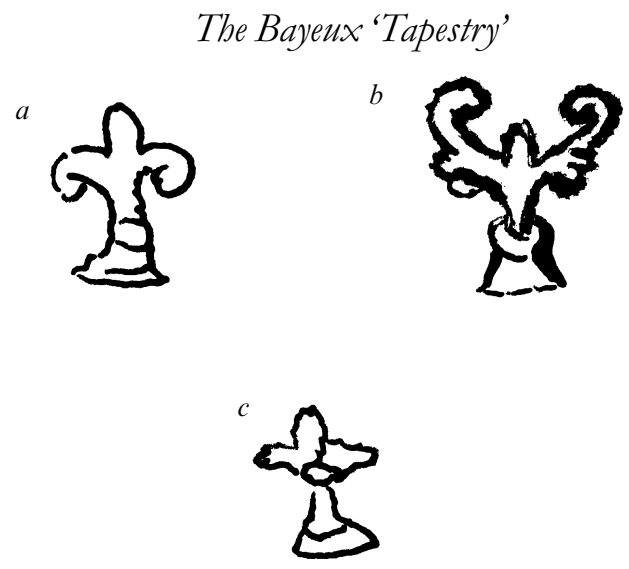

Fig. 7 Stylized plant motif: upper border, first section: trefoil-on-a-base (a); upper border, first section: acanthus-on-a-base $(b)$; lower border, second section: cross-on-a-base $(c)$

suggest that the junction area of the bottom border, both before and after the join, was created by the second workshop. The presence of an extra tree, accompanying an animal without a partner, to the left of the seam and an extra plant in its own space to the right of it indicate that considerable adjustment took place to avoid hiatus in the bottom border and thus to disguise the join.

When it happened again that the end of a scene coincided with the end of a length of linen, though there was little attempt to conceal the seam, the junction was managed much better (pl. IX). It occurs between the third and fourth sections, the loading of the invasion ships and the embarkation of William (scenes 37-8), but the sequence is smoothly handled here, with continuous treatment of the ground line and no interruption in the borders, only a wider-than-usual-gap in the main register betraying the join, so that the figures appear as a continuous procession. The viewer may not stop to think that realistically the provisions would be stowed first, before the passengers, though the Latin commentary makes this sequence clear.

Elsewhere the seams do not exactly coincide with the scene edges, though they are sometimes close to them in scenes $27-8$ (double numbering), ${ }^{18} 42^{19}$ and $55{ }^{20}$ In scenes $48^{21}$ and $51^{22}$ the seams are embedded within long scenes. In all these cases there is embroidery over the joins in the main register as well as the

18 Wilson, pl. 30. The seam passes through the man kneeling at the foot of the corpse.

${ }^{19} \mathrm{Ibid}$. pl. 47. The seam passes through the left hand of the man passing meat on sticks and through the roof of the building. $\quad{ }^{20}$ See below and pl. X, and Wilson, pl. 68.

21 Ibid. pl. 53. The seam passes through the overlapping horses between the two parts of the inscription.

22 Ibid. pl. 60. The seam passes between the legs of horses and through the body and head of horses and the foot and shield of a rider. 


\section{Gale R. Owen-Crocker}

borders, though there does not seem to have been any effort to maximize the covering, as could have been done, for example, by placing a rider on horseback right over the join. At the junction of the seventh and eighth sections (scene 55) the change of embroiderer is betrayed by a false fetlock on one horse and the incomplete leg and rump of another (pl. X). The embroiderer of section seven must have left the horse's forelegs incomplete, stopping at the fetlock of the right and perhaps, at the knee of the left leg, while embroidering a hoof in the bottom border. The embroiderer of the next section perhaps extended the horse's right leg over the join, and perhaps added the lower leg and hoof of the left leg - the knee joint and hoof are clumsy and the couching stitch changes direction below the knee. This left a disembodied hoof at the lower border, which has been attached to the horse at the opening of section eight by yellow stem stitch which is also added to the horse's tail. ${ }^{23}$

At the joining of the fourth and fifth sections (pl. XI) a different hand seems to have been in charge of the linkage from well before the end of section four (scenes 40-2) to part way into section five (scene 45). ${ }^{24}$ This is marked by a change in style, different from anywhere else in the 'Tapestry', distinguished by stiffer figures in angular costumes without contrasting borders. The pillaging scene is unusually spread out, with very little of the overlap which usually characterizes the figural style. Perhaps it was necessary to occupy a certain amount of space before the feast scene which was a measured distance from the scenes of Harold's worship and feast at Bosham and his oath at Bayeux (see below). It may well be that these significant events were designed to hang at particular points on the walls of the room the hanging was to decorate, thus underlining their interrelationship. The embroidery was not spontaneous, since at least some of the pillaging scene is based on a model, ${ }^{25}$ but there may have been some improvisation in the spacing of it.

The scenes are not of uniform length, and this makes for new, unintended boundaries and endings when the 'Tapestry' is reproduced in a book, which is the way most of us come to know it today. Wilson's beautiful facsimile is frustrating to work with in this respect, in that the page divisions cut through scenes, and the same images constitute the official photographs supplied by Bayeux. Many of the scenes are so long that they can only appear in a conventional-size book by splicing of plates and drastic reduction in size. Chopping up the scenes

${ }^{23}$ Both perhaps by a later hand? $\quad{ }^{24}$ Wilson, pls. 45-9.

25 The dependence of one figure on an image representing Labor in Cleopatra C. viii has been demonstrated by F. Wormald, 'Style and Design', The Bayeux Tapestry, ed. F. Stenton (London, 1957), pp. 25-36, pl. 47 and figs. 14 and 15. The depiction of the houses is suggestive of an attempt at perspective which might indicate a late antique model; P. Lasko, 'The Bayeux Tapestry and the Representation of Space', Medieval Art, ed. Owen-Crocker and Graham, pp. 26-39, at 29 . 


\section{The Bayeux 'Tapestry'}

is misleading, and order to appreciate the 'Tapestry' properly one must view it in its entirety, which is best achieved by use of one of the fold-out facsimile editions. ${ }^{26}$

\section{THE INTEGRITY OF THE DESIGN}

When the hanging is viewed as an entity, one can recognize that the clearly denoted scenes are much more than markers of time and place in a sequential narrative. There is a series of interrelationships between scenes, sometimes far apart. For example, the combination of religious ceremony and feasting which marks both the start of Harold's journey to the Continent (scene 3) and William the Conqueror's arrival from the Continent (scene 43) is an enclosing device that focuses attention on the irony of Harold's oath-taking (scene 23) which comes exactly between them $;{ }^{27}$ he swears (fealty to William, presumably) on a reliquary and an altar on which (arguably) the Eucharist, God's feast, is spread. ${ }^{28}$ Unusual brevity of scenes ${ }^{29}$ alerts us to the fact that Harold receiving arms from William and becoming his vassal (scene 21) bears a significant relationship to Harold's acceptance of the crown of England (scene 29) and consequent betrayal of William. ${ }^{30}$ There are many such anticipations and mirror images. Harold's sea voyage to Normandy, where the ships fill the upper border (scene 5), has an amplified echo in the voyage of William's conquering fleet from Normandy (scene 38), ${ }^{31}$ suggesting a significant relationship between the two events: whatever the purpose of Harold's visit to the Continent, it resulted in his acceptance of subservience to William and his oath. William comes to England to override Harold's claim to the kingdom and enforce his own. Little details, seemingly minor, bring events together: animals, hounds and hawk, carried towards Harold's boat for lordly sport (scene 4), are matched by other animals, a pig that is also carried, right to left this time, together with a sheep and ox, pillaged and butchered to feed the invaders (scene 41 ). ${ }^{32}$

Harold's adventures in Normandy prefigure graphically the events of William's adventure - the invasion of England. The Abbey of Mont SaintMichel (scene 16), standing on a semi-circular hill at the top of the main register and towering into the upper border, can be matched by the fortification built at Hastings (scene 45), also on a semi-circular hill at the top of the main register (fig. 8) ${ }^{33}$ Perhaps this was also intended to project into the upper border but was

26 The 'Tapestry' is reproduced in a continuous run, $1 / 7$ size, in La Tapisserie de Bayeux, Dessin de Roland Lefranc (Ville de Bayeux, undated) and La Tapisserie de Bayeux, Réalisation Edition Artaud Frères (Ville de Bayeux, undated). The way the 'Tapestry' is currently displayed, in a continuous curve away from the viewer, precludes the possibility of seeing the whole piece at one sweep. $\quad{ }_{27}$ Wilson, pls. 3, 25-6 and 48. $\quad{ }^{28}$ Owen-Crocker, 'Telling a Tale', pp. 52-4.

${ }^{29}$ Wilson, pls. 24 and 31. $\quad{ }^{30}$ Owen-Crocker, 'Telling a Tale', pp. 48-9.

31 Wilson, pls. 5-6 and 40-3. $\quad{ }^{32}$ Ibid. pls. 4 and 45-6. $\quad{ }^{33}$ Ibid. pls. 19 and 49-50. 


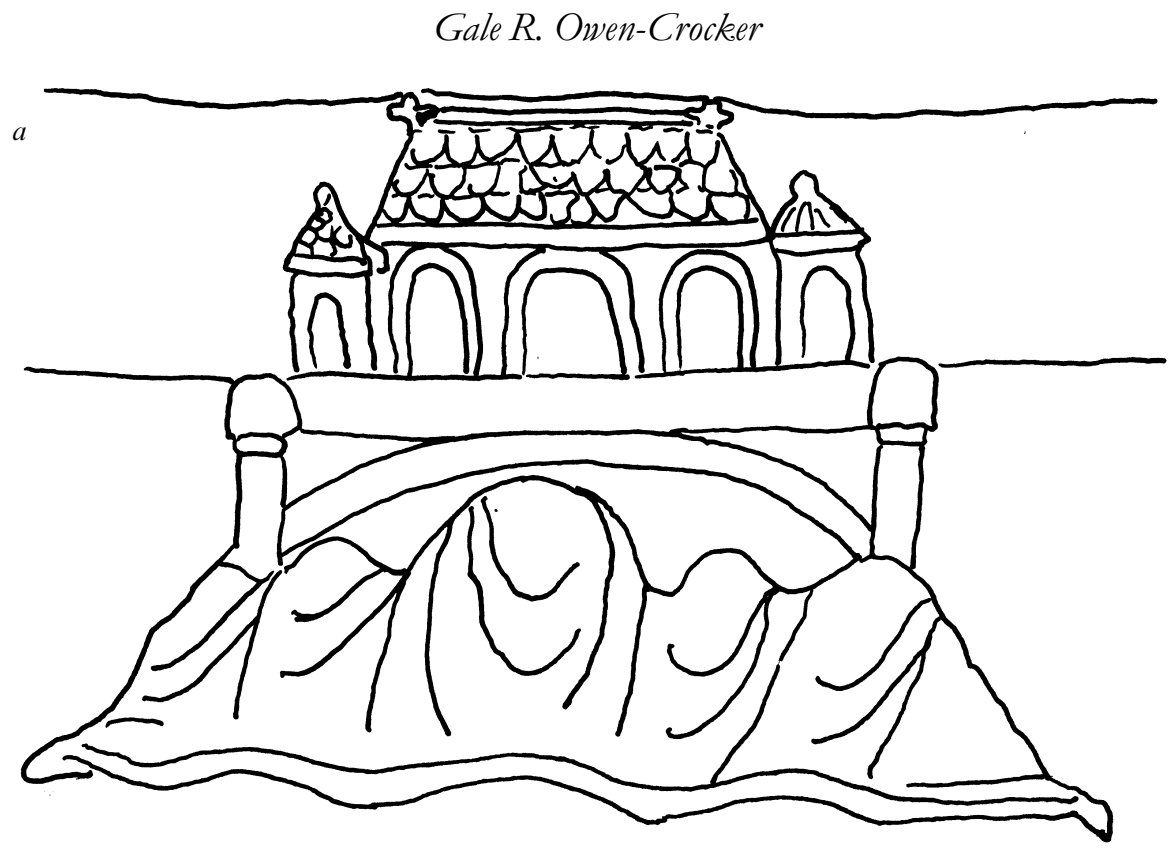

$b$

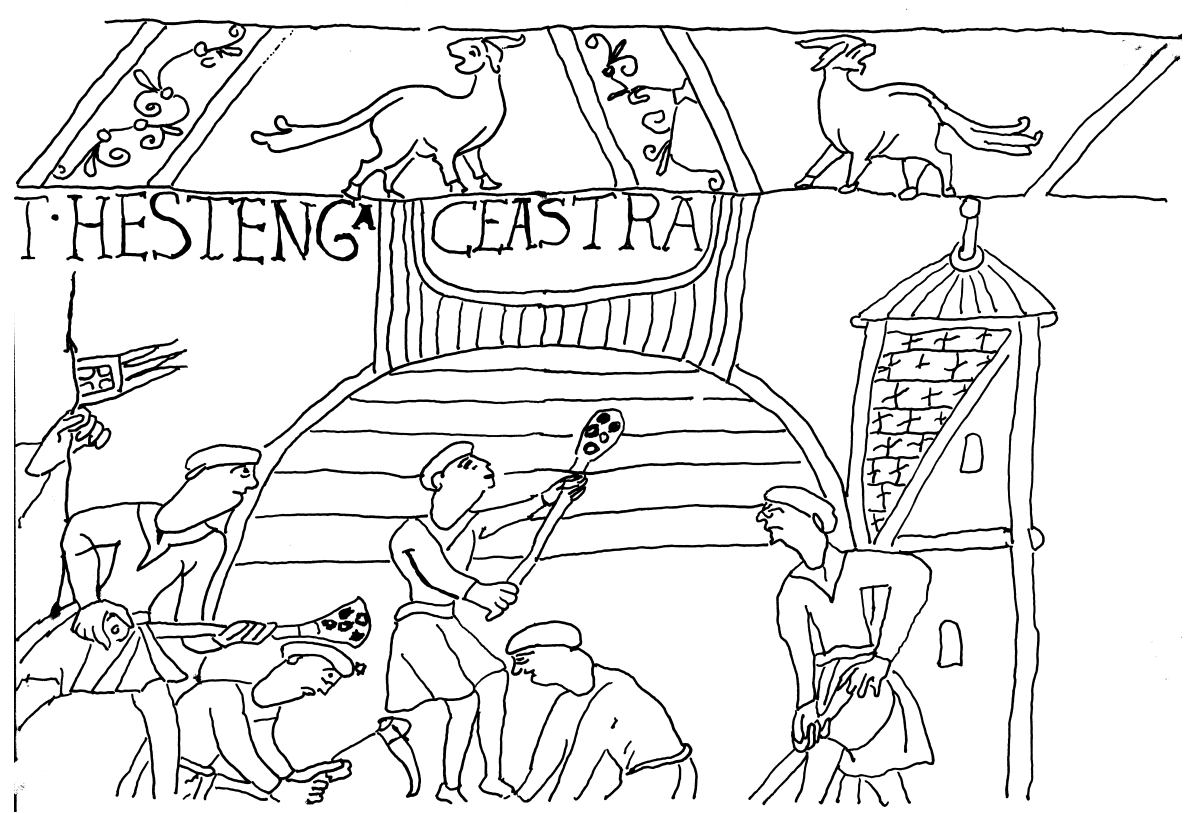

Fig. 8 Similar shapes: Mont Saint-Michel (a); fortification at Hastings $(b)$

266

https://doi.org/10.1017/S0263675102000108 Published online by Cambridge University Press 


\section{The Bayeux 'Tapestry'}

cut off because that was already embroidered. ${ }^{34}$ The escape of Conan from the siege of Dol (scene 18) is matched by the escape of a woman and child from a burning building (scene 47 ); ${ }^{35}$ not only is the escape motif repeated, but the shapes of the structures are similar: in each case there is a roof, on a rectangle, on a subrectangle, on a semi-circle (fig. 9). ${ }^{36}$ The theme of burning begins with the firing of the town of Dinan (scene 19) ${ }^{37}$ and is echoed in the destruction of the woman's house. The assaults on Rennes, which is depicted as a building on a hill grazed by sheep (scene 18), and on Dinan, which is vigorously defended from above by the men of Brittany, can be matched by Norman horsemen on a hill (scene 49) and the English defence of an unidentified knoll in the Battle of Hastings itself (scene 53). ${ }^{38}$ Harold had distinguished himself by a rescue of men from the quicksands around Mont Saint-Michel, watched by Bishop Odo, among others, identifiable by his costume and club (scenes 16-17). ${ }^{39}$ Immediately after the defence of the knoll it is Bishop Odo himself who is the man of action, galloping into the fray to encourage the troops (scene 54$).{ }^{40} \mathrm{With}$ his mount at full stretch, Odo on horseback is the widest figure in the 'Tapestry'. In his distinctive clothing and in the front range of horsemen in the scene, Odo is even more impressive a hero than Harold rescuing two men simultaneously. It seems likely that when the 'Tapestry' was hung, this figure of Odo would be prominently displayed and it would relate, spatially, to the scene of Harold's resourcefulness.

34 It seems possible that the embroiderers of the main register were forced to adapt the design, and to move the hill down, because the border was already completed. The identifying Latin caption is awkwardly spaced, and the final ceastra is (uniquely) placed inside the embroidered building. One of the diggers overlaps the hill in a way that is unusual - figures are normally set against plain back-cloth - although the technique is repeated soon after with the figure of the woman fleeing the burning building. $\quad 35$ Wilson, pls. 21 and 50-1.

36 Conan escapes from the turretted roof of a two-storey building on a hill with two birds on it The woman's house has a pitched roof over an upper storey above a lower area of roof. The semicircular zone is the lower storey of the building from which the two figures emerge.

37 Wilson, pl. 23. ${ }^{38}$ Ibid. pls. 21-2, 23, 55-6 and 66-7.

39 Ibid. pls. 18-20. In identifying this figure as Odo I disagree with other commentators (J. B. McNulty, The Narrative Art of the Bayeux Tapestry (New York, 1989), p. 100; Wilson, p. 179) who interpret the man in the multicoloured, checkered garments, carrying a club, as William. By the artist's rules of overlap (below, n. 43), this cannot be William. The Duke must be the figure to the left in elaborate armour holding a standard, who is overlapped by no-one. The figure in the checkered garment is surely Odo, who is dressed in the same way at the Battle of Hastings, where he also carries a club and is identified in the caption: Odo Eps.bacvlv. tenens... 'Bishop Odo holding a club'. The bishop would not have been permitted to carry weapons and does not wear conventional armour. One might not have expected the bishop to ride a stallion, but Odo does so on the battlefield; so the fact that the figure in checkered garments at the quicksands is mounted on a stallion does not preclude his identification as Odo. I am grateful to Sarah Keefer for discussing the horses in the 'Tapestry' with me.

40 Wilson, pl. 67. 
Gale R. Owen-Crocker

$a$

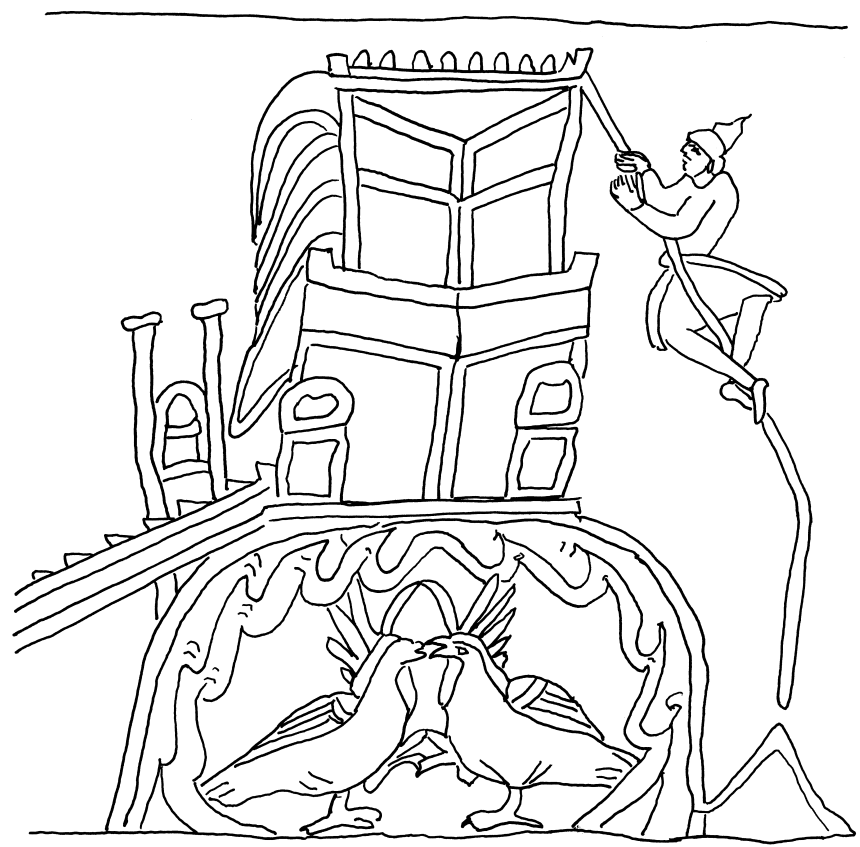

$b$

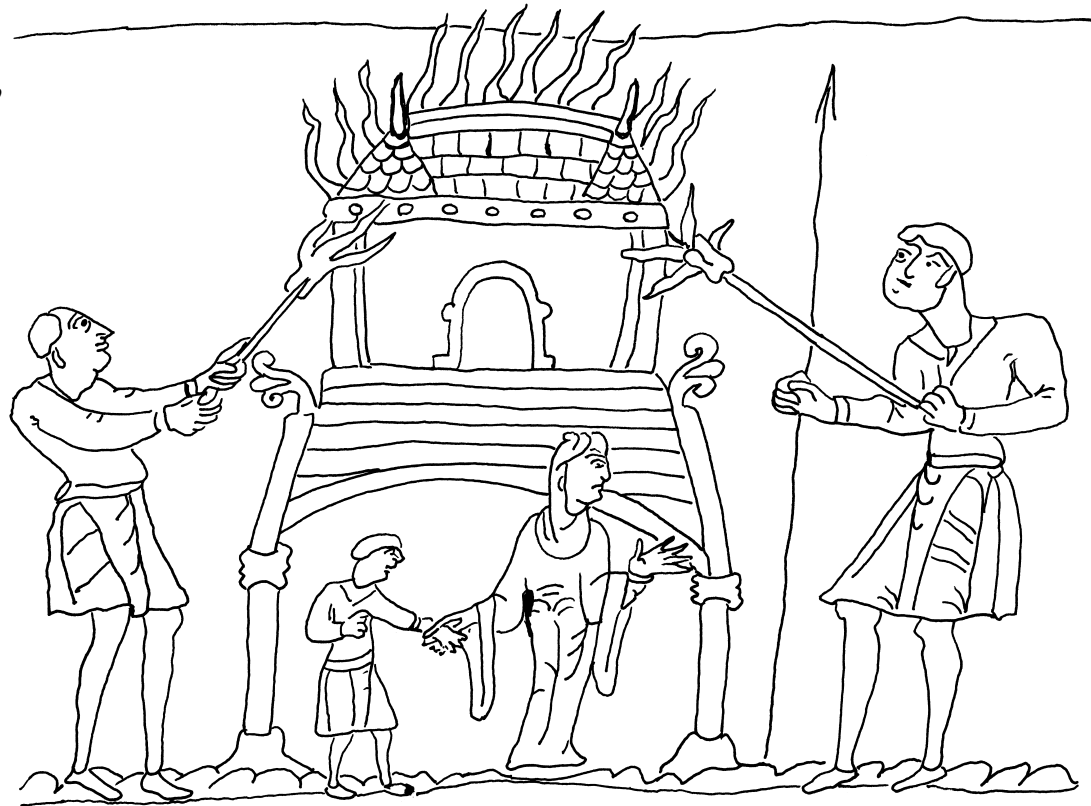

Fig. 9 Similar shapes: Dol (a); Woman's house (b)

268 


\section{The Bayeux 'Tapestry'}

Edward's splendid funeral procession (scene 26), right to left, in which bearers shoulder the bier, using walking sticks to steady themselves, where acolytes dangle bells and clerics clutch books and crozier (fig. 10), finds its transformation in the procession of supplies towards the invasion fleet (pl. IX). ${ }^{41}$ Again it is small details which alert us to the way the artist echoes, inverts and reinforces the image. This time shafts on shoulders support mailcoats. The walking stick is there again, steadying the man who drags the wine cart. The mailcoats dangle now, swords are clutched and weapons are held forward to replace the crozier. Both processions are the result of Edward's death. Edward's deathbed itself (scenes 27-8), where the king is attended by his family and priest, will shortly be followed by another family meeting in a building (scene 35), where William and his brothers, Odo significantly tonsured, discuss the consequences of Edward's death and Harold's succession. ${ }^{42}$ In both scenes the hands of the figures are an important indicator of what is being said: the dying Edward gives the throne to Harold, who gestures astonishment, thumb towards face; Edith, wife of Edward and sister of Harold, points to her brother. Odo clearly recommends invasion in an authoritative manner. ${ }^{43}$ The throne of England must be William's, not Harold's.

The Latin commentary, meanwhile, simply identifies the events depicted in each scene, dry and brief like a series of annals, using the formulas bic or ubi. It is not in the commentary but in the images that we are invited to see a meaning, a moral, a pattern to events. This, then, is the reason why the makers stitched together the strips of linen into a continuous whole. It might have been physically easier to create a series of separate hangings but that was not the intention. They were constructing a single, complex entity with a meaningful design.

\section{THE BORDERS}

In considering the integrity of the whole work, we must not forget that the narrative frieze is constrained between borders. There is some debate about whether the borders are ornamental or meaningful. ${ }^{44}$ Some of Aesop's fables, once seen as purely decorative, ${ }^{45}$ are now sometimes seen as windows through

${ }_{41}$ Ibid. pls. 29-30 and 38-9. $\quad{ }^{42}$ Ibid. pls. 30 and 34-5.

43 Though Odo is placed behind William as appropriate to the relative rank of the two brothers (see McNulty, The Narrative Art, p. 51), his throne is higher and he gestures expansively, right hand open and left pointing forward to woodcutters, carpenters and invasion. William's inward pointing hand movements could be interpreted as a firm 'I will do this', but if compared with Harold's gesture as he stands arrested and disarmed by Guy of Ponthieu (scene 8) has more of a weak 'Who? Me?' about it. It is as if the invasion is Odo's idea. The third figure, presumably the brother Robert who is identified later, is standing, smaller, and entirely deferential to William.

${ }^{44}$ Hicks, 'The Borders', pp. 264-5. Hicks argues that the borders are purely ornamental.

45 As Hicks points out (ibid. p. 253), there is no consensus about how many scenes illustrate the fables of Aesop. 


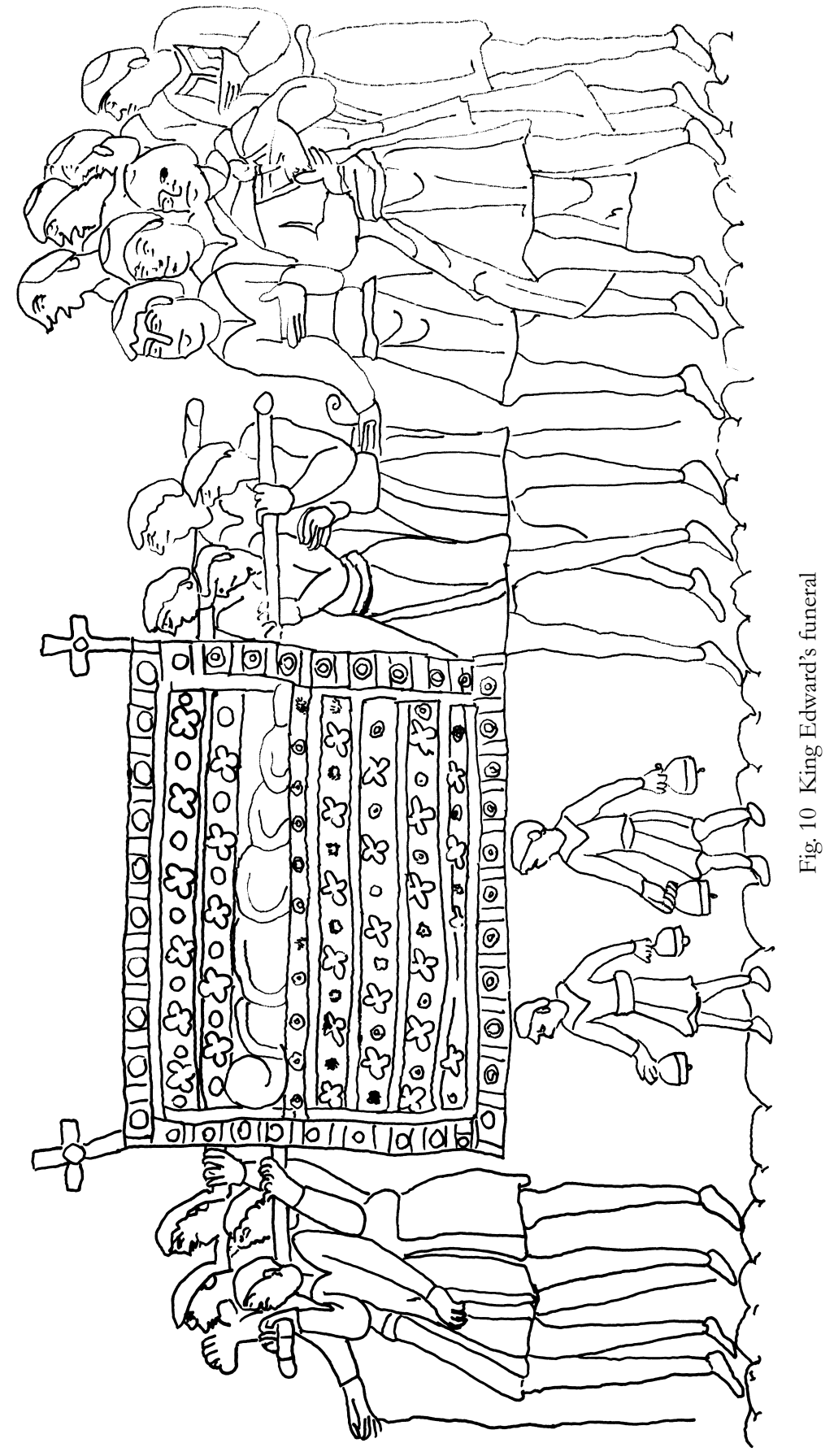




\section{The Bayeux 'Tapestry'}

which the main action may be interpreted. ${ }^{46}$ For much of the 'Tapestry' the borders are occupied by pairs of birds and animals like heraldic beasts, but they too may provide a form of annotation to the narrative. ${ }^{47}$ Lions, for example, coincide with the presence of King Edward. ${ }^{48}$ The borders sometimes offer a commentary in a different voice from that of the main frieze; sometimes ironic, but often reflecting simple human emotions like enjoyment, shock and fear, contrasting with the courage, ambition and hubris of the aristocratic, 'heroic' dramatis personae of the main register. Birds in the lower border imitate the reverent attitude of Harold and his companion as they enter church, and animals join in the subsequent feast: while the men above drink, the animals eat what look like sausages (scene 3). ${ }^{49}$ The upper border creatures either hang their heads in shame or peer down in horror when Harold is arrested (scene 6), ${ }^{50}$ and take an enthusiastic interest in the siege of Dol (scene 18). ${ }^{51}$ They look horrified when Normans are trapped in the quicksands (scene 17) ${ }^{52}$ and get quite interested in a scrap between two Norman engineers (scene 45). ${ }^{53}$ As the Normans ride out in splendid array to battle, birds in the upper border preen themselves, flanked by naked human beings (scene 48). ${ }^{54}$ The man fetches his saddle and axe, the man and woman come together for what may be the last time. ${ }^{55}$ As the battle reaches its most violent, with axes and swords biting into the flesh of men and horses, and both soldiers and their mounts plunging onto their heads, birds in the upper border trail tendrils of fruiting vegetation, ironic doves of peace with olive branches (scene 53). ${ }^{56}$

At some points, the borders are invaded. The fleets crossing the channel displace the usual birds and beasts from the upper level (scenes 5 and 38$)^{57}$ conveying the enormity of the sea and, in the case of the invasion, the enormity of the event. The dismembered corpses of the Battle of Hastings replace the creatures out of the bottom border (scenes $51-8)^{58}$ which amplifies the conflict so that it does not seem like a distant heroic battle, but a violent and painful happening in which all share. For us the 'Tapestry' ends with chaos and slaughter, as the last birds in the bottom border recoil (scene 51). ${ }^{59}$ In a final touch of grim humour

46 S. Bertrand, 'Étude sur les bordures de la Tapisserie de Bayeux', Bulletin de la Société des sciences, arts et belles-lettres de Bayeux 24 (1961), 115-24.

47 Bernstein, The Mystery, pp. 128-74; McNulty, The Narrative Art.

48 There are, however, 140 examples of lions, not all associated with Edward; see Hicks, 'The Borders', p. $258 . \quad{ }^{49}$ Wilson, pl. $3 . \quad{ }^{50}$ Ibid. pls. 6-7.

$51 \mathrm{Ibid}$. pl. 20. The fact that the interested animals are a pair of boars, notoriously fierce, reflects the ferocity of the assault. $\quad{ }^{52} \mathrm{Ibid}$. pls. 19-20. $\quad{ }_{53} \mathrm{Ibid}$. pl. $49 . \quad{ }^{54} \mathrm{Ibid}$. pls. 52-3.

${ }^{55} \mathrm{I}$ am alone in seeing the figures as reflecting the stark pathos of war's separation. The naked border figures are usually seen as gratuitous obscenity.

57 Lasko, 'The Bayeux Tapestry', p. 30, and figs. 8 and 9.

56 Wilson, pls. 65-6.

59 Ibid. pl. 61.

58 Wilson, pls. 61-7 and 70-3. 


\section{Gale R. Owen-Crocker}

little dragons flee through the battlefield, scuttling under the horses' hooves and clinging to a standard (scene 57), ${ }^{60}$ escaping their long confinement in a border which is no longer safe.

\section{AN IMAGINED ENDING}

This was not the original ending. The conclusion to the hanging and thus to the story seems to have been missing by the early eighteenth century and possibly more has been lost in the course of its various adventures, such as the occasion when, for once, the 'Tapestry' was treated as textile rather than art and taken to cover a wagon during the Franco-Prussian War. ${ }^{61}$ The recognition of structural relationships between the scenes means that we can speculate with some confidence about what might have been. I am not alone in thinking that the end of the 'Tapestry' would have shown William crowned king of England. ${ }^{62}$ I would add that he would be facing forward, on a high throne under a wide canopy and that he would be elaborately dressed in long garments. This would echo and mirror the enthroned figure of Edward the Confessor at or near the beginning, ${ }^{63}$ a framing device making the 'Tapestry', like Beowulf, 'an opposition of ends and beginnings'. ${ }^{64}$

The story takes us from the end of one era into another. Edward the Confessor, the last reigning Anglo-Saxon king of Alfred's line, is briefly replaced by an Anglo-Scandinavian upstart, brave but presumptuous, crowned by an excommunicated archbishop. ${ }^{65}$ England will finally be left to begin a new reign and a new dynasty in the safe hands of William the Norman, divinely legitimized to our eyes by his papal standard and the counsel of his half-brother the bishop, Odo of Bayeux. Although his appearances in the 'Tapestry' are few, Odo's importance is clearly implied there. If he commissioned the work it would not be surprising if he figured with William in the final scene. The 'Tapestry' opens with King Edward and his trusted brother-

${ }^{60}$ Ibid. pl. 71. ${ }^{61}$ Brown, The Bayeux Tapestry, p. 9.

${ }^{62}$ Bernstein, The Mystery, p. 25; C. R. Dodwell, The Pictorial Arts of the West 800-1200 (New Haven, CT, 1993), p. 12; M. Rud, The Bayeux Tapestry and the Battle of Hastings 1066 (Copenhagen, 1988), p. 93 and fig. Jan Messent's recent reconstruction of the end of the hanging, sponsored by Madeira Threads, depicts William's coronation.

${ }^{63}$ S. Bertrand, 'Étude sur la Tapisserie de Bayeux', Annales de Normandie 10 (1960), 197-206, points out that most of the opening border has been restored. Part of the main register could be therefore be missing.

${ }^{64}$ J. R. R. Tolkien, 'Beowulf: the Monsters and the Critics', PBA 22 (1936), 245-95, at 271-2. Possibly the missing part would have included William taking an oath at the altar to defend the church and rule justly, as recorded in a Worcester Chronicle (cited by Rud, The Bayeux Tapestry, pp. 92-3). This would neatly contrast with Harold's perjury; though it does not accord with my own view of the design of the 'Tapestry' which will be developed in a forthcoming article.

${ }^{65}$ Wilson, pl. 31. 


\section{The Bayeux 'Tapestry'}

in-law Harold, and another figure, perhaps meant to represent one of Harold's brothers, the Leofwine and Gyrth who are among the casualties of the Battle of Hastings. ${ }^{66}$ I would guess that it ended with King William and his trusty half-brothers, the insignificant Robert and the magnificent Odo.

66 They are named at Wilson, pls. 63-4. 


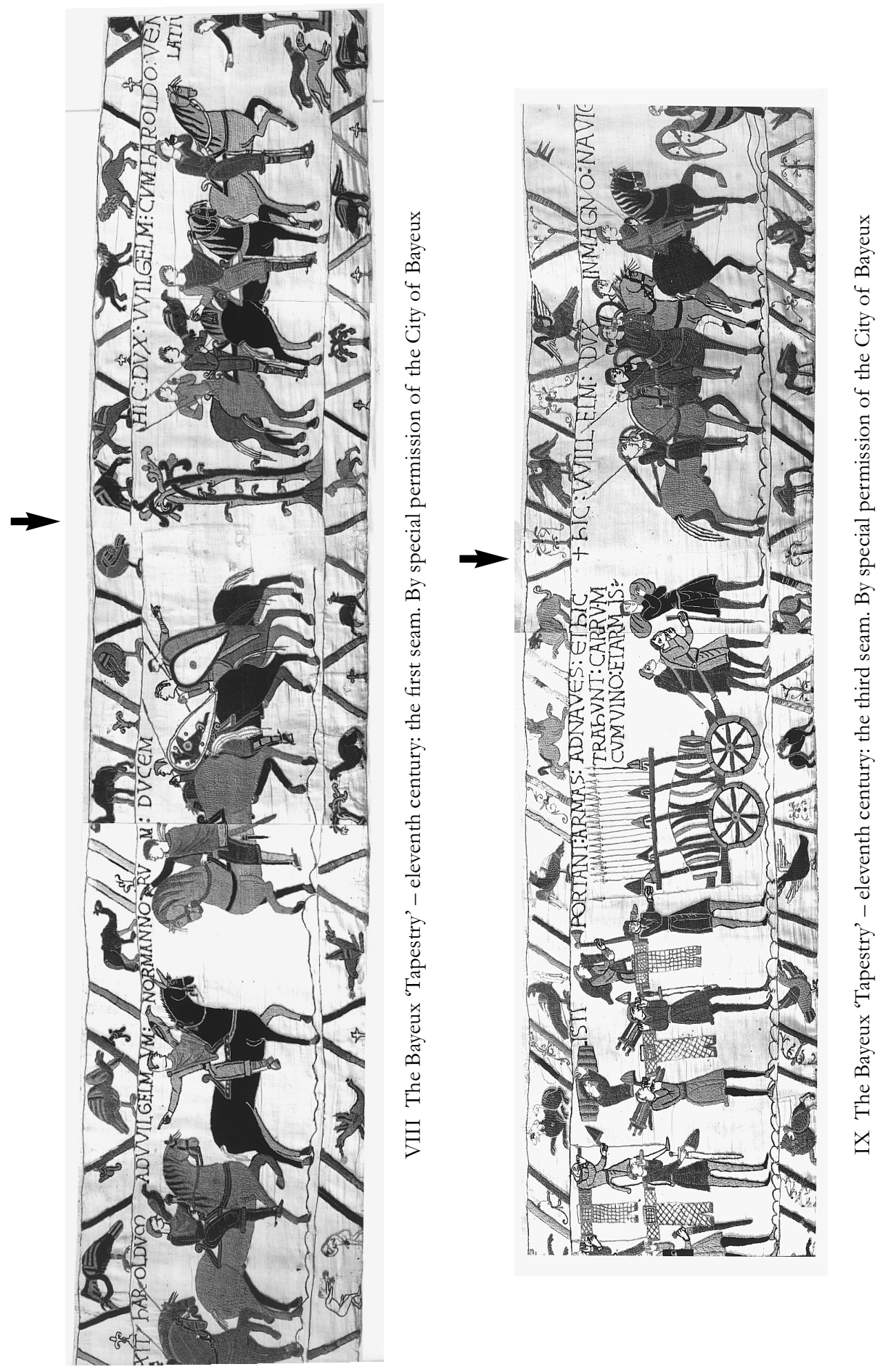




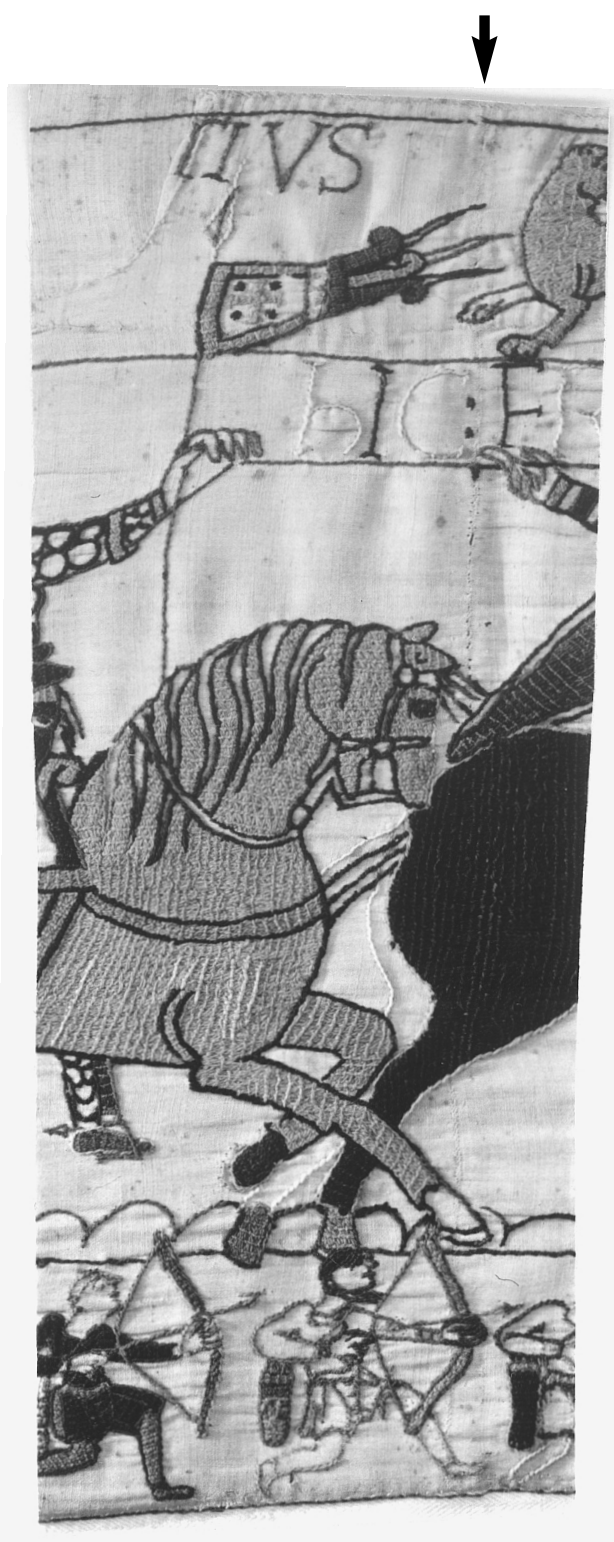

$\mathrm{X}$ The Bayeux 'Tapestry' - eleventh century: the seventh seam. By special permission of the City of Bayeux 


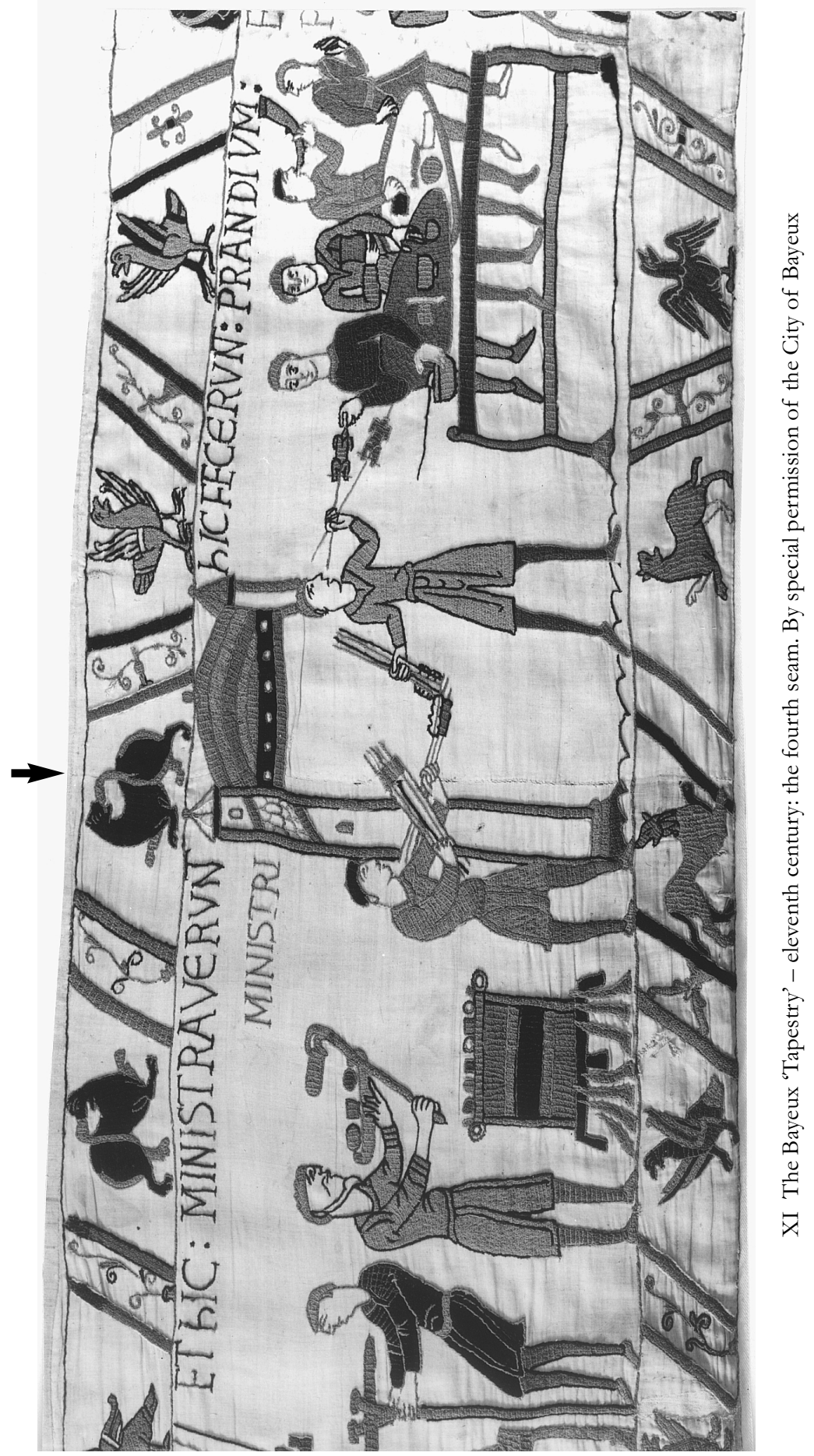

